慶應義塾大学学術情報リポジトリ

Keio Associated Repository of Academic resouces

\begin{tabular}{|c|l|}
\hline Title & Hereditary cataract of the Nakano mouse \\
\hline Sub Title & \\
\hline Author & 竹鼻, 顚(Takehana, Makoto) \\
\hline Publisher & 共立薬科大学 \\
\hline Publication year & 1990 \\
\hline Jtitle & $\begin{array}{l}\text { 共立薬科大学研究年報 (The annual report of the Kyoritsu College of } \\
\text { Pharmacy). No.35 (1990.) ,p.48-48 }\end{array}$ \\
\hline JaLC DOI & \\
\hline Abstract & \\
\hline Notes & 抄録 \\
\hline Genre & Technical Report \\
\hline URL & https://koara.lib.keio.ac.jp/xoonips/modules/xoonips/detail.php?koara_id=AN00062898-0000003 \\
\hline
\end{tabular}

慶應義塾大学学術情報リポジトリ(KOARA)に掲載されているコンテンッの著作権は、それぞれの著作者、学会または出版社/発行者に帰属し、その権利は著作権法によって 保護されています。引用にあたっては、著作権法を遵守してご利用ください。

The copyrights of content available on the KeiO Associated Repository of Academic resources (KOARA) belong to the respective authors, academic societies, or publishers/issuers, and these rights are protected by the Japanese Copyright Act. When quoting the content, please follow the Japanese copyright act. 


\title{
Hereditary Cataract of the Nakano Mouse
}

\author{
Makoto TAKEHANA
}

\section{竹鼻 眞}

The Nakano mouse cataract is inherited as an autosomal recessive trait. It was originally discovered by Dr. Kennji Nakano in 1957. Animals from this strain open their eyes on day 14, the same as normal mice, at which time the lenses of the Nakano mice are still clear. Homozygous animals develop a pin head opacity in the nucleus of the lens on the 24 th postnatal day, and over the next 36 days the cataract becomes mature.

This paper will review recent advances in the study of the Nakano mouse system. It will include studies of cation levels, morphology, lens implantation, capsule glycosaminoglycan synthesis, and predicted gap junctional activity in the lenses from Nakano and normal mice.

The Nakano mouse is a hereditary cataract model whose most characteristic change is a deficiency in lens $\mathrm{Na}^{+}, \mathrm{K}^{+}$-ATPase. The amounts of calcium in also change suddenly in the lens, with accumulated levels higher than any other type of cataract. Other biochemical changes coincide with the development of lens opacity, including decreases in the levels of reduced glutathione, ATP, biosynthetic activity of proteoglycans in epithelial cells, and the permeability of gap junction channels in fiber cells. The decrease in the activity of $\mathrm{Na}^{+}, \mathrm{K}^{+}$-ATPase results in changes in a number of key metabolic parameters, resulting in the eventual opacification of the Nakano mouse lens at approximately 30 days of age.

* 本報告は Exp. Eye Res（1990）50，671-676に発表. 